\title{
Collections for the poor: monetary charitable donations in Dutch towns, c. $1600-1800$
}

\author{
DANIËLLE TEEUWEN*
}

ABSTRACT. In many localities in the Dutch Republic, charitable collections were the single largest source of income for relief institutions for the outdoor poor. This article takes into account both the role of the authorities organising collections and the role of the city-dwellers making charitable donations. It is demonstrated that people from almost all layers of urban society contributed to the collections. By means of thorough planning and exerting social pressure, religious and secular administrators of poor relief tried to maximise Dutch generosity. They presented making charitable donations as a duty of the rich as well as of the less well-off. In the Dutch Republic, not only the elites, but also the middling groups of society, who approximately constituted almost half of the urban population, were of vital importance in financing poor relief.

\section{INTRODUCTION}

Early modern poor relief has often been defined as an interaction between two social groups: the elites and the poor. ${ }^{1}$ Both groups profited from a well-functioning poor relief system. The elites' collective interest lay in social and economic stability, and charity served as an important 'control strategy' to achieve this. Poor relief enabled regulation of the labour market, prevented public disorder, and consolidated the existing social hierarchy. The poor, who struggled daily to make ends meet, had a variety of 'survival strategies' to which they could resort. They could beg, steal, pawn their goods, migrate, ask for help from neighbours, family and friends, and, additionally, they could apply for relief from charitable

\footnotetext{
* International Institute of Social History, Amsterdam.
} 
institutions. Rich and poor depended on each other. They were bound together by what has been called a 'perpetual commerce of charity'. ${ }^{2}$

This model clearly simplifies a more complex reality. In the process of charitable giving and receiving, more than two social groups were involved. Particularly when we look at the Dutch Republic, which has often been characterised as the first 'bourgeois' society, it becomes clear that the role of the middling groups of society needs to be taken into account. The Dutch Republic, which between roughly 1580 and 1670 experienced a 'Golden Age' with a long period of economic growth coupled with a dominant position in world trade, was the most urbanised region in Europe. At the end of the seventeenth century, approximately 45 per cent of the population lived in towns and cities; in the province of Holland, the urbanisation rate was over 60 per cent. ${ }^{3}$ In these cities, the middle class, a diverse group, which included entrepreneurs, small to middling traders, lower urban officials, shopkeepers and skilled craftsmen, probably constituted almost half of the population. ${ }^{4}$ Although middle-class citizens were excluded from official political power, they were engaged in commerce and trade, joined craft guilds, neighbourhood associations, and urban militias, contributed to the economic prosperity of the region, and dominated urban social life. ${ }^{5}$

Living standards in the Dutch Republic were probably the highest in Europe, and all inhabitants, including migrants and women, profited from the favourable labour market. ${ }^{6}$ However, in spite of the enormous increase in wealth from the late sixteenth century onwards, it was also a period of growing social inequality. ${ }^{7}$ A substantial part of society lived close to or below subsistence level. Estimates on the part of the population who during the Golden Age came to rely on distributions of money, bread and peat by charitable institutions vary from 10 to 25 per cent. ${ }^{8}$ The majority of the inhabitants in early modern Dutch cities depended on wage labour and lived in nuclear families, which made them vulnerable to economic hardship. ${ }^{9}$ The risk of falling into poverty was not only lurking for the old, sick or unemployed; it could also happen to the middling sorts.

In addition to informal support by friends, family and neighbours, an extensive network of public and private charitable institutions existed that alleviated the suffering of the destitute. The poor could not live on the assistance offered by these institutions alone. They had to employ different strategies to make ends meet. ${ }^{10}$ Still, Peter Lindert has estimated that around 1790, England and Wales and the Dutch Republic probably had the highest per capita expenditure on poor relief in Europe. ${ }^{11}$ Based on the economic development of these two countries in the seventeenth and eighteenth centuries, it can be assumed that the Northern Netherlands 
had the highest level of charitable expenditure in the period before 1790 . This generosity towards the poor can be explained by the overall wealth in the country, as well as by the vulnerability of a large part of Dutch society to economic hardship. Providing relief for those in need was crucial for the stability of society.

Not only the elites paid for the support of the less fortunate. In financing poor relief, the middling groups of society were of vital importance. Charity in the Dutch Republic was partially funded with public subsidies, deriving from excise taxes, to which everyone contributed. ${ }^{12}$ However, it was not just through tax money that the less well-off paid their share. In many cities, especially in the seventeenth century, coins collected in the churches and the streets formed the main source of income of poor relief institutions. Churches collected donations during services and doorto-door collections took place frequently. Small amounts were also donated to alms boxes, which were located in strategic places in the cities, such as inns, the town hall and on ferries.

In contrast to England, where poor relief was financed by a compulsory tax based upon property, no national legislation concerning social care existed in the Dutch Republic. Charitable institutions offering assistance to the outdoor poor, defined as the destitute who lived in their own homes instead of institutions such as orphanages and hospitals, depended mainly on the population's generosity. In principle, charitable giving was anonymous and voluntary; donations could not be enforced by law. However, as will be argued here, collections had a semi-obligatory character. The authorities conveyed that contributions were expected from the rich as well as the less well-off. Only the destitute themselves were excused. By means of thorough planning and exercising social pressure, religious and secular poor administrators tried to maximise Dutch generosity. As a result, even people from the lower strata of society participated in this monetised charitable system.

Despite the importance of collections and alms boxes for the financing of outdoor poor relief, a systematic and comparative analysis of gifts by these means within the Dutch Republic is still lacking. ${ }^{13}$ This article attempts to fill this lacuna, by comparing financial data of charitable organisations and collection revenues in four Dutch towns in the seventeenth and eighteenth century. The four towns, Delft, Utrecht, Zwolle and 's-Hertogenbosch, were situated in different parts of the Dutch Republic, and had distinct economic and social characteristics. ${ }^{14}$ In Delft, in the province of Holland, where the prosperity of the Golden Age was concentrated, industries and international trade flourished. The trade of Utrecht, Zwolle and 's-Hertogenbosch was more directed towards their own regions. Utrecht was characterised by a relatively large, wealthy 
upper class of regional nobility and an urban patriciate. Moreover, in Utrecht as well as in 's-Hertogenbosch, a large share of the population remained loyal to the Catholic Church after the Reformation.

There were also major organisational differences between these cities regarding the relationship between public and private charitable institutions. In Delft and Zwolle, poor relief functioned - at least during the major part of the seventeenth and eighteenth century - as a fully centralised municipal poor relief system. In Utrecht, both urban administrators as well as deacons were responsible for the destitute. In 's-Hertogenbosch, the poor could only turn to private institutions.

To examine how the Dutch managed to substantially finance their relatively generous and oft-praised charitable system by voluntary collections, one first needs to examine the role of almoners and deacons who organised them. How frequently did collections take place? Were closed boxes or open plates used? How were the inhabitants of the Dutch Republic encouraged to contribute? Next, the role of the donors will be examined. What factors influenced the level of generosity of Dutch city-dwellers? Did everyone comply with the duty to donate to collections? The methods used to answer these questions are both qualitative and quantitative. Minutes and resolutions of charities provide more insight into the organisation of collections and the tactics employed by authorities to encourage people to donate lavishly, while registers of collections and account books of poor relief institutions reveal how much was given to different charitable causes, what factors influenced the philanthropic gift, and, occasionally, even how many people donated.

Motivations behind charitable giving can be numerous and multilayered, such as sincere compassion, fear of social unrest and a feeling of commitment to urban society. Early modern charity was, moreover, highly religiously motivated; the message that remembering the poor was a religious duty was preached in the churches frequently..$^{15}$ For small gifts, such as the coins put in offertory boxes, motivations are more difficult to uncover. The urban context, and the well-developed civil society and powerful civic institutions in the Dutch Republic, as has been described above, will be used to explain the early modern Dutch giving behaviour.

\section{ORGANISING AND FINANCING POOR RELIEF}

Before we turn to the organisation of collections, and the donations to them, let us first examine the organisation of early modern Dutch poor relief. In the Dutch Republic, there was no uniform tax system to finance poor relief. Welfare was considered virtually a local matter. ${ }^{16}$ Each city and town, as well as many villages, had their own arrangements. 
An extensive network of public and private institutions existed, such as hospitals, almshouses and orphanages caring for the needy within the walls of the institutes, as well as religious and secular organisations that distributed money, bread and peat for the 'outdoor poor'. In the sixteenth century, population growth and increasing pressure on existing social provisions, supported by humanistic ideas about poverty and charity, had stimulated poor relief reforms in large parts of Europe. Southern German towns were the first to reorganise charitable provisions. Such initiatives were replicated quickly in several cities in the south of the Low Countries. In the Northern Netherlands, reforms were only implemented after the Reformation, around $1600 .{ }^{17}$

Because of the relative autonomy of Dutch cities, the reorganisational process had a different outcome in different cities. In Delft and Zwolle, provisions for the outdoor poor were fully centralised. The Delft Chamber of Charity (Kamer van Charitate) was established in 1597 and was charged with providing assistance to all city-dwellers, regardless of their religious beliefs, from 1614 onwards. The same was true for the City Poor Chamber (Stadsarmenkamer) in Zwolle from 1616 onwards. Both organisations were supervised by the municipal authorities. In Utrecht, the Reformed deacons were initially responsible for the care of all poor, including the non-Reformed. From 1628 onwards, the Reformed deacons only assisted the poor of their own church, while the newly created Almoners' Chamber (Aalmoezenierskamer) provided relief for all the other poor and needy in the city. In 's-Hertogenbosch, provisions were never centralised. Besides the various diaconates, which took care of their own poor, secular organisations operated as they had since the late Middle Ages. No civic institution was established here after the Reformation. ${ }^{18}$ The biggest poor relief organisation in 's-Hertogenbosch was the Table of the Holy Ghost (Tafel van de Heilige Geest), commonly referred to as the 'House of Giving' (Geefhuis). However, the Reformed diaconate and nine district-based institutions, the Blocks (Blokken), had a substantial budget as well. ${ }^{19} \mathrm{~A}$ 'mixed economy of welfare' emerged in the Dutch Republic, in which both public and private institutions took responsibility for the poorest in society. ${ }^{20}$

In cities where centralised public institutions existed, the Catholic, Mennonite, Lutheran and Walloon poor could turn to the urban administrators for assistance, although they often had some additional arrangements for their fellow church members as well. However, from the second half of the seventeenth century onwards, religious minorities were increasingly excluded from public provisions. In 1674, the Utrecht Catholics were told to take care of their 'own' poor henceforth. In Delft, several religious minorities received the same news at the end of the 
seventeenth century. ${ }^{21}$ In Zwolle, the Catholics and Lutherans could no longer turn to the City Poor Chamber from 1739 onwards. A Reformed Poor Chamber was established in $1756 .{ }^{22}$ In this process, which has sometimes been referred to as a 'confessionalisation' of poor relief, charity became more and more divided along religious lines. ${ }^{23}$

In contrast to the deacons of minority churches, who could only support their fellow church members from charitable gifts and interest on capital and property, most Reformed charities and urban poor relief institutions profited to a greater or lesser extent from municipal subsidies. The city-run charities in Delft, Zwolle and Utrecht, as well as the Reformed diaconate in 's-Hertogenbosch, received a share of the city's excise tax income, and also various fines and small fees paid to the city council were frequently handed over to the poor. ${ }^{24}$

Sometimes extraordinary subsidies were granted in times of financial trouble. As a consequence, tax money seeped through to the charity funds. In some cities a more direct poor tax existed that yielded small sums of money for the charitable institutions. In Delft, if someone died or was buried in the city, the best garment of the deceased had to be donated to the Chamber of Charity. ${ }^{25}$ In Utrecht, citizens had to pay a few guilders to let the bells of the Dom Church ring on the occasion of a death. ${ }^{26}$ With the downward economic trend in the eighteenth century, leading to increasing urban poverty, some public charities gradually depended more on subsidies from city governments.

In 's-Hertogenbosch, the authorities rarely interfered in the finances of charities. The House of Giving and the Blocks had all built up considerable endowments during the late Middle Ages. They received income from investments in farms and estates, house rents and state bonds. In the second half of the eighteenth century, some 95 per cent of the income of the House of Giving was derived from interest on capital and property income; for the Blocks, this was about 75 per cent. Such assets were managed with great care. Reckless investments or sales could lead to major financial difficulties in the years to come. Other charities also invested in bonds and annuities, or owned some real estate, although often not on the same scale as their counterparts in 's-Hertogenbosch. ${ }^{27}$

In the city of 's-Hertogenbosch, charitable donations were almost of negligible importance for the financing of poor relief. During the eighteenth century about 15 per cent of the total income of the major charitable institutions - the House of Giving, the Blocks and the Reformed diaconate - proceeded from collections and gifts. The House of Giving, which was the biggest institution, did not hold collections at all. However, 's-Hertogenbosch, with its large medieval charitable assets, seems to have been an exception in the Dutch Republic. 
In many cities, especially during the prosperous years of the Golden Age, charitable donations formed the single largest source of income for the financing of poor relief. Money was collected in the churches and in the streets on a regular basis. Every once in a while, larger sums were donated or bequeathed to the charities. In the seventeenth century, twothirds of the income of the City Poor Chamber in Zwolle came from collection revenues (see Table 1). In Delft and Utrecht, this figure was over 40 per cent. ${ }^{28}$ Not only diaconates profited from church collections. In Zwolle and Delft, money that was collected in the churches was handed over to the urban institutions. Urban administrators as well as deacons went door-to-door to ask for a charitable donation.

Alms boxes usually yielded relatively small sums of money. In Delft during the seventeenth and eighteenth century, on average only 6.4 per cent of collection revenues came from poor boxes. ${ }^{29}$ In Zwolle, this figure was about 3.6 per cent. ${ }^{30}$ Although alms boxes were usually situated in public places, making a donation to such a box was the most anonymous and voluntary charitable act possible. Unlike the situation with collections in churches and in the streets, when donating to alms boxes every form of social pressure was absent, and this may explain why so little was given this way. Apparently the inhabitants of the Dutch Republic needed to be encouraged to donate to charitable causes. What tactics the authorities applied to maximise collection revenues will be discussed in the next section.

\section{ORGANISING COLLECTIONS}

The multitude of institutions depending on the population's generosity could easily have led to chaos in which the plethora of almoners and deacons who carried collection boxes bumped into each other in the streets. However, the public authorities monitored collections and prevented such disorder. To collect within a single city, the permission of the municipality was required. To collect in a larger area, requests had to be sent to the provincial authorities or the States General. These requests were not always granted. In December 1778, an appeal of the authorities of the partially burnt down village of Giesendam to take up a collection in Delft was refused because the municipality of Delft worried that the annual Christmas collection, held on the 26th of December, would yield fewer revenues. ${ }^{31}$ In November 1800 , the city authorities determined that a collection for the village of Asperen, that had also been partly devastated by a fire, had to be postponed until after the Christmas collection for the Chamber of Charity. ${ }^{32}$ The collection that the Catholic Poor Chamber held every four weeks in Zwolle was scheduled eight days after the one for 


\section{TABLE 1 \\ Percentage of income of selected charitable institutions raised through collections and alms boxes ${ }^{a}$}

\begin{tabular}{lcc}
\hline \hline & 17th century & 18th century \\
\hline $\begin{array}{l}\text { Delft } \\
\text { Chamber of Charity }\end{array}$ & 45 & 37 \\
Zwolle & 66 & 42 \\
$\begin{array}{l}\text { City Poor Chamber } \\
\text { Utrecht }\end{array}$ & 42 & 13 \\
Almoners' Chamber & No data & 60 \\
Reformed diaconate & 0 & 0 \\
'-Hertogenbosch & 17 & 21 \\
House of Giving & No data & 26 \\
Blocks & & \\
Reformed diaconate & & \\
\hline \hline
\end{tabular}

${ }^{a}$ The data for Zwolle and Utrecht have partly been processed by Elise van Nederveen Meerkerk. For none of these institutions has the financial administration survived for two entire centuries. For the Delft Chamber of Charity, data on 1614, 1624-1626, 1628 and 1641-1800 were used; for the City Poor Chamber in Zwolle, data on 1656-1683, 1692-1694, 1723, 1743-1793 and 1795-1800; for the Utrecht Almoners' Chamber, data on 1630-1637 and 1639-1794; for the Reformed diaconate in Utrecht, data on 1727-1731 and 1776-1800, although the accounts on July 1790-July 1792 were incomplete and have therefore not been used in the sample; for the Reformed diaconate in 's-Hertogenbosch, data on 1735-1764 and 1766-1800. The percentages for the Blocks in 's-Hertogenbosch are estimates. Data have been gathered for every 10 years for the period 1600-1800 from the 9 different financial administrations. There are no data available for every Block for all the sample years, and years have sometimes been substituted by years for which data were available. Also, the Blocks received a small part of their income in rye, which has not been converted to guilders. However, the percentages of the second half of the eighteenth century do not differ significantly from the data that José de Kruif has gathered for that period, in which legacies and gifts are also included, see de Kruif, 'De prijs van de armenzorg'.

Sources: Archives Delft, Chamber of Charity, inv. nos 208, 287-290; Historical Centre Overijssel (HCO), City Poor Chamber, inv. no. 91; HCO, City Archives, inv. nos 10105-10111, 10124-10125; Utrecht Archives (UA), Almoners' Chamber, inv. no. 1827; UA, Reformed diaconate, inv. nos 538-551; City Archives 's-Hertogenbosch (CAH), Blocks, annual account books block A to I; CAH, Reformed diaconate, inv. nos 257-294. The data of the House of Giving are based on José de Kruif, 'De prijs van de armenzorg. De financiering van de armenzorg in Den Bosch 1750-1900', Tijdschrift voor Sociale Geschiedenis 20 (1994), 24-51 and A. C. M. Kappelhof, 'Het Bossche Geefhuis. Het inkomen uit het vermogen van de Tafel van de H. Geest van Den Bosch 1450-1810', Varia Historica Brabantica 10 (1981), 1-54.

the City Poor Chamber. ${ }^{33}$ Thus, the authorities were aware that the generosity of the donors was finite and avoided overburdening the citydwellers, a phenomenon which we call today 'collection fatigue'. ${ }^{34}$ Raising enough money for the city poor was the main priority for the 
authorities. Collections for external causes were only allowed if no negative consequences for regular collections were expected.

In spite of the strict planning by authorities, collections still took place frequently. Collection bags were passed in the Reformed churches during services, which could be held up to five times a week. ${ }^{35}$ The Walloons, Lutherans, Catholics and Mennonites also held collections in their churches, though they sometimes preferred just to place an offertory box at church doors. ${ }^{36}$ In Utrecht, weekly door-to-door collections were organised by the Almoners' Chamber in all the city districts and extra collections were held four times a year. The inhabitants of Delft were also asked weekly to donate to the city poor, as well as on 26 December. The City Poor Chamber in Zwolle collected every four weeks. In addition, the Catholic Poor Chamber collected every four weeks and every three months from Catholic households, while the Reformed Poor Chamber held a public collection from 1772 onwards. In 's-Hertogenbosch, the Blocks arranged a charitable appeal at Easter and Christmas in addition to weekly collections that were held from 1652 onwards. ${ }^{37}$

It was not only charities entrusted with the care of the outdoor poor that made their rounds through the cities; sometimes other institutions, such as orphanages, followed suit. For example, in 's-Hertogenbosch, the Civic Orphanage went door-to-door at Easter and Christmas. In the late 1770s, the Catholic Orphanage was permitted to do the same in May and November but collectors were restricted to visiting only Catholic homes. ${ }^{38}$ Moreover, in the same city, money was raised for poor prisoners twice a week.$^{39}$ Furthermore, in all parts of the Dutch Republic, collections were sometimes undertaken for external purposes, such as for the assistance of Protestant minorities abroad, the building or rebuilding of churches, or to support inhabitants of burnt down Dutch cities. Organising collections was also a way to raise extra money if charities experienced financial troubles. ${ }^{40}$

Moreover, as noted above, small coins were also collected more passively. For those who sometimes wished to make a charitable donation more spontaneously, an extensive web of alms boxes existed in the cities. In 's-Hertogenbosch, a network of some 60 poor boxes covered the city. In Amsterdam, there were about 450 boxes. The boxes were mainly situated in public places, such as in inns and the town hall. Sometimes people - for example, ministers - kept them in their homes. ${ }^{41}$ Making small charitable donations was practically a daily habit in the Dutch Republic.

Public collections - at least the more irregular ones - were announced in the churches and near the city hall. People thus were informed when to expect an almoner, deacon or district warden on their doorstep so they 
could have small change close at hand. In contrast to making charitable bequests, in which donating was a private decision, ${ }^{42}$ social pressure to contribute to a church or public collection was high. If a deacon or almoner asked for a donation, failure to give would be conspicuous. The easiest way out was to put a coin of low value, a foreign coin or a worthless piece of metal in the offertory bag. ${ }^{43}$

Sometimes social pressure was increased further, when open plates rather than closed boxes or bags were used. This allowed the almoner or deacon not only to see if one gave, but also how much was donated, which led to higher levels of generosity. In Delft, the open plate or 'schael' was used for the annual collection on 26 December. In 's-Hertogenbosch, the Blocks collected with open plates at Easter and Christmas. This tactic was also used in churches, especially at the Lord's Supper, or Communion, and on days of prayer the offertory bags were exchanged for plates. ${ }^{44}$

Sending people of high status door-to-door was another tactic used to foster high levels of generosity. When magistrates or ministers came to ask for a charitable contribution, it was difficult to be stingy. Such methods were also used during collections for external causes as, for example, in Delft in 1749, when money was raised for the rebuilding of churches in Bergen op Zoom and Sas van Gent and also for the assistance of victims of the War of the Austrian Succession in Brabant and Flanders. ${ }^{45}$

The tactics employed by the almoners and deacons were so successful that collections were often a stable source of income for charities. For example in Delft, from 1641 to 1794, about 20,000 guilders were collected in the churches and streets in almost every year (see Figure 1). When, in times of financial difficulties, charities requested extra support from the municipal authorities, they justified their appeals by saying that the collections had gained fewer revenues than previous years, which had caused the deficit in their account books. ${ }^{46}$

However, in the Dutch Republic, to donate was not merely a social expectation, it was in fact presented as an obligation the city-dwellers had towards the poor. ${ }^{47}$ Sometimes, it was stressed that especially those who had been blessed by the Lord with 'temporary goods' were expected to make charitable contributions, but often the authorities announced that collectors would visit every single house. ${ }^{48}$ The Delft authorities admonished all city-dwellers to fulfil their obligation towards the poor. If people were unable to be at home to donate, they had to ask someone - a family member, for example - to give on their behalf. ${ }^{49}$ Sir William Temple also noticed this somewhat obligatory character that formed the foundation of the Dutch charitable system. Immediately following his often quoted assertion that, 'Charity seems to be very National among 


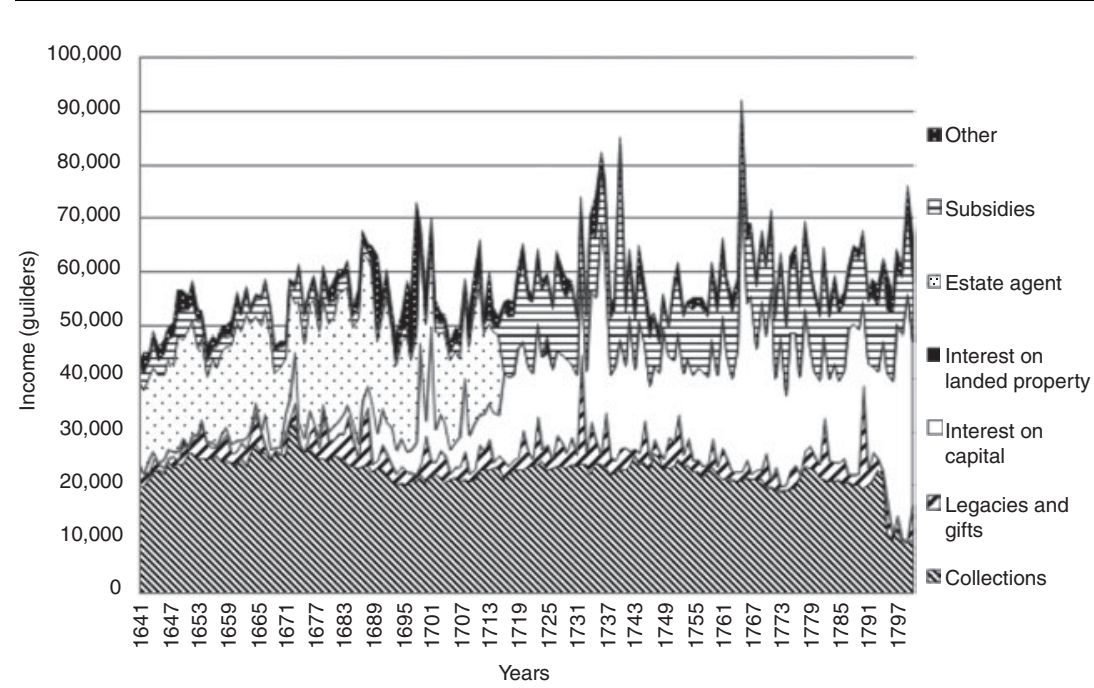

Figure 1. Annual income by source of the Delft Chamber of Charity, 1641-1800. These data have not been corrected for inflation. For an overview of the income structure of the Chamber of Charity corrected for inflation, see Figure 5. The income of the estate agent includes revenues from subsidies as well as interest on landed property and capital; the account books give more details from 1716 onwards. (Sources: Archives Delft, Chamber of Charity, inv. nos 287-290.)

them,' he argued that, 'though it be regulated by Orders of the Country, and not usually mov'd by the common Objects of Compassion. ${ }^{50}$

Was Temple right in his observation that the Dutch needed some degree of compulsion to be generous? It could be argued that the authorities had to encourage the city-dwellers' generosity repeatedly because of the large numbers of misers who tried to escape their obligation towards the poor. The social pressure was no doubt important, considering the fact that, as stressed above, the alms boxes often only yielded small sums of money. Still, charitable gifts financed a substantial part of poor relief and, as we shall see, there are several indicators that a large part of society contributed. That Dutch generosity had not reached its limit was, however, proven in Sneek, a small town in Frisia, where in 1775 giving by charitable gift was exchanged for a compulsory contribution and the income received increased. ${ }^{51}$

Regarding English poor relief, it has been widely debated whether the obligatory nature of poor relief caused a decline in voluntary charitable donations. ${ }^{52}$ Similarly for the Dutch Republic, it is difficult to assess the influence of the semi-obligatory character of the collections on other types of giving. It is, for example, impossible to compare collection gifts with 
forms of informal aid. Looking at testamentary bequests and inter vivos gifts, it becomes clear that these donations contributed far less to the total income of charitable institutions than collections did. Elise van Nederveen Meerkerk shows in her article in this special issue that in Leiden and Utrecht, some 10 to 20 per cent of wills contained testamentary bequests to poor relief institutions. However, in Zwolle, where the people drew up their last wills at the Bench of Aldermen instead of at private notaries, the percentages were far higher. ${ }^{53}$ As not every city-dweller made a will, and only a small proportion of those who did so in Leiden and Utrecht left anything to charity, only a small minority of the populations of these cities decided to donate to charity after their death. Whether this was caused by the semi-obligatory character of the collections, or by other circumstances, is difficult to say at this point.

\section{DONATING TO COLLECTIONS}

Who contributed to charitable collections in the Dutch Republic, and how much individual donors gave, is almost untraceable for the presentday historian. Only the almoners and deacons who requested charitable contributions in the churches and in the streets knew who contributed, who did not, and, sometimes they even knew how much was given. However, somewhat scattered archival sources located in the four cities under scrutiny help us to draw a clearer picture of the donors, using the money they put in the collection bags and offertory boxes as a key. In this section, it will first be argued that a large majority of the population contributed to charitable collections. Next, it will be demonstrated that people donated according to what they could afford. Thus - at least in absolute terms - the rich gave more than the poor. Although revenues were often stable, there was a multitude of factors that influenced this type of charitable giving, and these will be set out in the last part of this section.

A collection held in the 1660s for the building of a new orphanage, the Holdehuis, in Zwolle demonstrates that a large majority of the city's population responded to the charitable appeals of the urban and religious poor relief administrators to donate generously. First, probably in 1664 and early 1665 , the city-dwellers were asked how much they wanted to contribute. These amounts were listed per household in four registers. Most money was collected during the years 1665 and 1666; the last payment was made in 1671. The year 1665 was a turbulent year in Zwolle because the bishop of Münster threatened to attack the city, which led many families to flee to safer areas. A total of 2,055 heads of household was noted in the collection registers. Of them, 1,903 were present at the time the enquiry was made, of whom 82 per cent donated. 
When someone did not contribute, often an explanation was noted in the register, such as that somebody was too poor to do so or had died. ${ }^{54}$ Tax registers reveal that in 1665 there were 1,558 occupied houses in the city. In 1670, when the threat of war had been averted, the number increased to $2,733 .{ }^{55}$ It is uncertain if all households were included in the register. It is possible that the poorest were not asked because the authorities knew that their requests would be in vain. Still, the vast majority of the inhabitants of Zwolle contributed to the financing of the Holdehuis.

For the collections for the charities in the city that took place on a regular basis, it is more difficult to establish what part of the urban population contributed. Registers of collections held every four weeks for the City Poor Chamber in Zwolle do hint, however, that the majority of the inhabitants also gave on these occasions. For example, in 1735, every four weeks, approximately 3,800 coins were collected (see Table 2). In this period, there were in total some 2,400 houses in the city, which means that on average about 1.5 coins per house were collected each time. ${ }^{56}$ The majority of the coins collected consisted of duiten, the smallest coin possible, and stuivers, respectively 61 and 22 per cent of the total. Because of this high number of small coins, it seems highly probable that a large number of people individually donated one or two coins. It is unlikely that a small, wealthy minority of the city population used small coins to make substantial donations. If a rich merchant wanted to donate a guilder, he would not use 160 duiten or 20 stuivers to do so, but rather give a guilder.

Assuming that the lower social groups donated duiten, which did not contribute substantially to the income of charitable institutions, the higher middle classes and the elites, who donated larger coins, were the predominant contributors to the collection revenues, which led to money transfers from these social groups to the poorest of the urban society. The authorities urged every inhabitant to contribute to collections, but the well-to-do were expected to give more than their poorer fellow citydwellers. People were asked to donate according to what they could afford ${ }^{57}$ In Delft, the proceeds of several door-to-door collections were documented per district. These records make it possible to link the average level of wealth within a certain part of the city, as indicated by tax registers, to the amount of money collected. Both sources are available for the year 1749. On 16 June of that year, when money was collected for the war-affected areas of Brabant and Flanders, notably more money per household was donated in districts 12,13 and 14 than in other parts of the city (see Figure 2). The tax registers, in which all Delft households were registered per district, report not only the amount of taxes people had to pay, but also their occupation and whether they depended on poor relief. 
TABLE 2

Number of different types of coin collected during 13 door-to-door collections for the City Poor Chamber in Zwolle in 1735

\begin{tabular}{|c|c|c|c|c|c|c|c|c|c|c|c|c|c|c|c|}
\hline Type of coin (value in stuivers, st.) ${ }^{a}$ & 1 & 2 & 3 & 4 & 5 & 6 & 7 & 8 & 9 & 10 & 11 & 12 & 13 & Total & $\%$ of total \\
\hline Zilveren rijder (63 st.) & 1 & 1 & 1 & 1 & 1 & 1 & 1 & 1 & 1 & 1 & 1 & 1 & 1 & 13 & 0.03 \\
\hline Driegulden (60 st.) & 2 & 2 & 3 & 2 & 2 & 2 & 1 & 1 & 1 & 2 & 1 & 2 & 1 & 22 & 0.04 \\
\hline Zilveren dukaat (50 st.) & 6 & 4 & 4 & 4 & 4 & 3 & 6 & 4 & 3 & 4 & 4 & 4 & 5 & 55 & 0.11 \\
\hline Halve zilveren rijder (31.5 st.) & 0 & 0 & 0 & 0 & 1 & 0 & 0 & 0 & 0 & 0 & 0 & 0 & & 1 & 0.00 \\
\hline Daalder (30 st.) & 3 & 1 & 5 & 2 & 1 & 2 & 2 & 2 & 3 & 2 & 3 & 3 & 2 & 31 & 0.06 \\
\hline Florijn (28 st.) & 17 & 18 & 11 & 13 & 14 & 13 & 13 & 14 & 11 & 14 & 14 & 15 & 19 & 186 & 0.37 \\
\hline Halve zilveren dukaat (25 st.) & 2 & 1 & 1 & 3 & 2 & 2 & 1 & 3 & 3 & 0 & 1 & 3 & 3 & 25 & 0.05 \\
\hline Gulden (20 st.) & 26 & 23 & 23 & 23 & 21 & 24 & 25 & 20 & 23 & 21 & 24 & 21 & 26 & 300 & 0.60 \\
\hline Dertiendehalf (12.5 st.) & 1 & 4 & 4 & 3 & 6 & 5 & 2 & 3 & 1 & 2 & 5 & 3 & 1 & 40 & 0.08 \\
\hline Zesdehalf (5.5 st.) & 226 & 236 & 235 & 242 & 234 & 257 & 249 & 213 & 216 & 240 & 208 & 220 & 263 & 3,039 & 6.11 \\
\hline Dubbele stuiver (2 st.) & 400 & 430 & 405 & 375 & 368 & 370 & 330 & 350 & 327 & 320 & 400 & 325 & 355 & 4,755 & 9.56 \\
\hline Stuiver & 790 & 820 & 845 & 810 & 765 & 770 & 897 & 880 & 830 & 820 & 815 & 855 & 805 & 10,702 & 21.51 \\
\hline Duit (1/8 st.) & 2,496 & 2,288 & 2,384 & 2,240 & 2,288 & 2,384 & 2,432 & 2,496 & 2,288 & 2,256 & 2,352 & 2,352 & 2,320 & 30,576 & 61.47 \\
\hline Total & 3,970 & 3,828 & 3,921 & 3,718 & 3,707 & 3,833 & 3,959 & 3,987 & 3,707 & 3,682 & 3,828 & 3,804 & 3,801 & 49,745 & \\
\hline
\end{tabular}

a A stuiver was worth 0.05 guilders. Apart from duiten, which were copper coins, only silver coins were donated to these collections. During the first half of the eighteenth century, almost two-thirds of the silver coins that were produced in the Dutch Republic were guilders (with a value of 20 stuivers); only 1 per cent of the silver coins produced was a stuiver: Jan Lucassen, 'Wage payments and currency circulation in the Netherlands from 1200 to 2000 ', in Jan Lucassen ed., Wages and currency. Global comparisons from antiquity to the twentieth century (Bern, 2007), 221-63. The daily wage of an unskilled labourer in the Eastern part of the Netherlands, where Zwolle was located, in the period around 1735 was approximately 12 stuivers, a master's wage was about 20 stuivers: Jan de Vries and Ad van der Woude, The first modern economy: success, failure and perseverance of the Dutch economy, 1500-1815 (Cambridge, 1997), 612-13.

Source: Historical Centre Overijssel, City Poor Chamber, inv. no. 240. 


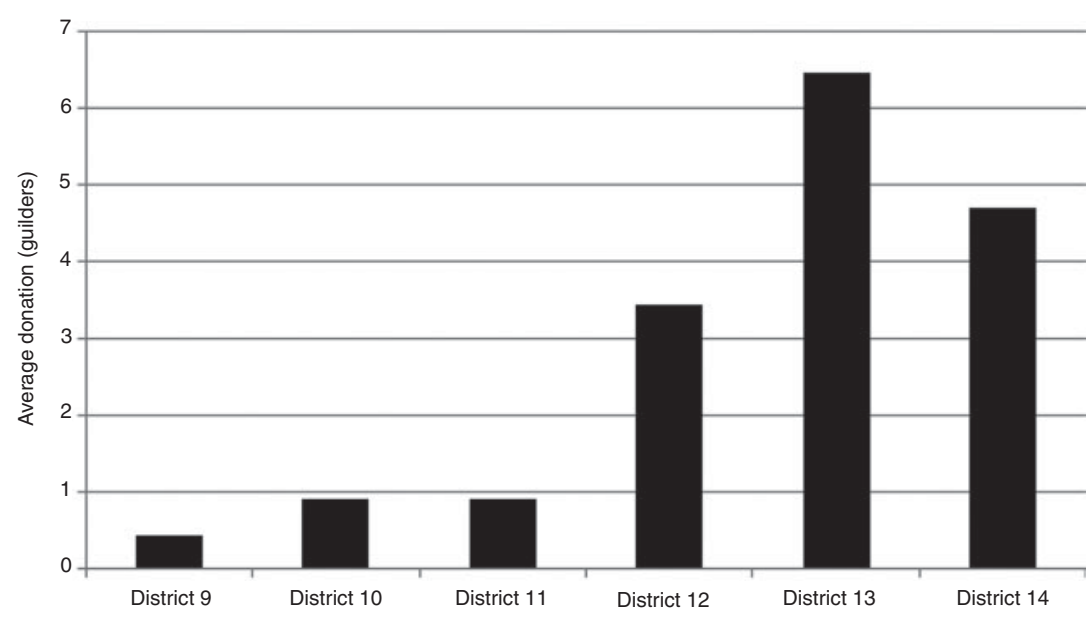

FIGURE 2. Average donation per household to a collection in six districts of Delft, 1749. The district numbers are given in both the collection register and the tax registers. (Source: Archives Delft, Old City Archives I, inv. no. 1727.)

Comparing the three districts with high collection revenues with three districts with much lower revenues reveals that in the parts of the city where less taxable wealth was found, lower donations to the public collection were made (compare Figures 2 and 3). Hence, the rich donated - at least in absolute terms - more than the poor.

When we look a bit more closely at the social and occupational composition of these six city districts, it becomes clear that in the more generous districts, the elites and middle classes were overrepresented. These districts all include a part of the Oude Delft, an area where high-ranking persons, such as burgomasters, lived. In the districts where much less was collected, the lower social strata were highly represented (see Figure 4). ${ }^{58}$ Households in district 12 donated far less than one might expect based on the level of taxable wealth in this part of the city. In this small district, a few extremely wealthy families inflated the level of the average assessed taxes disproportionally. In contrast, district 13 housed the political elite of the city: three burgomasters, two former burgomasters, and several former aldermen lived in these streets. Moreover, on average, the number of household members in district 12 was the highest of these six districts, which may have caused a lower level of generosity.

The inhabitants of the Dutch Republic had been assigned by the authorities the responsibility to finance a substantial part of their poor relief system. Why did they adhere to this expectation and fulfil this duty so painstakingly? An answer can be found when looking at why the Dutch 


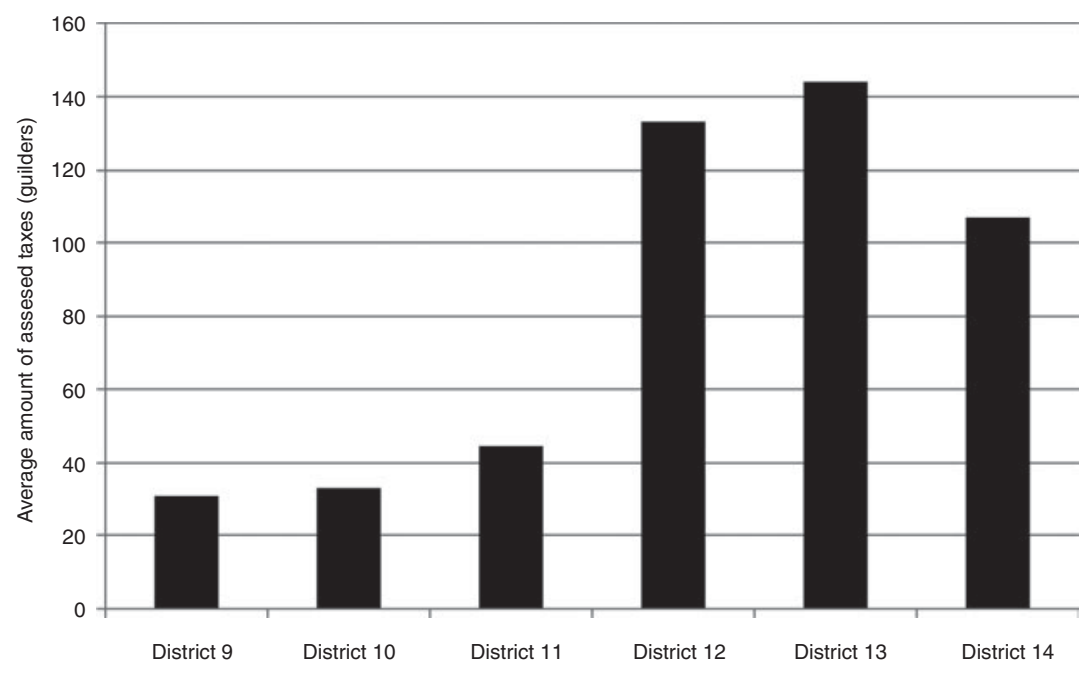

Figure 3. Average amount of assessed taxes in six districts in Delft, c. 1749. In 1748 and 1749 the gemene middelen ('common means'), largely consisting of excises, were not collected and were temporarily replaced by the provisioneel middel. The level of this provisional tax was based on an estimation of family consumption, linked to the economic position of the households; see H. A. Diederiks, D. J. Noordam and H. D. Tjalsma, eds., Armoede en sociale spanning: sociaal-historische studies over Leiden in de achttiende eeuw (Hilversum, 1985), 11, 38; F. P. Wagenaar, "Dat de regeringe niet en bestaet by het corpus van de magistraet van Den Hage alleen": de Sociëteit van 's-Gravenhage (1587-1802): een onderzoek naar bureaucratisering (Hilversum, 1999), 105. For the assessment, a distinction was made between taxation at the national and at the city level; the amounts per household have been summed here. The assessed taxation on commercial activities, as well as whether the assessed amounts were really paid, has not been taken into account. (Source: Archives Delft, Old City Archives I, inv. no. 602.)

also submitted to the highest level of taxation in Europe. According to Marco van Leeuwen, the high quality of social welfare for the middling groups in society, such as the assistance offered by guilds and burgher orphanages, encouraged these groups to accept the financial burden without reaping the benefits of political influence. ${ }^{59}$ Maarten Prak and Jan Luiten van Zanden use the notion of 'citizenship' to explain why the Dutch Republic more successfully collected taxes than more oppressive regimes. They argue that people are more willing to pay taxes if they can influence public authorities to some degree, can expect everyone to pay their fair share and can see that the money is spent wisely. ${ }^{60}$ In 1748 , the 'Liberal Gift', a one-off two per cent property tax, was collected in the Dutch Republic, for which the inhabitants of Zwolle were allowed to assess themselves. Closed boxes were used to collect the money but, 


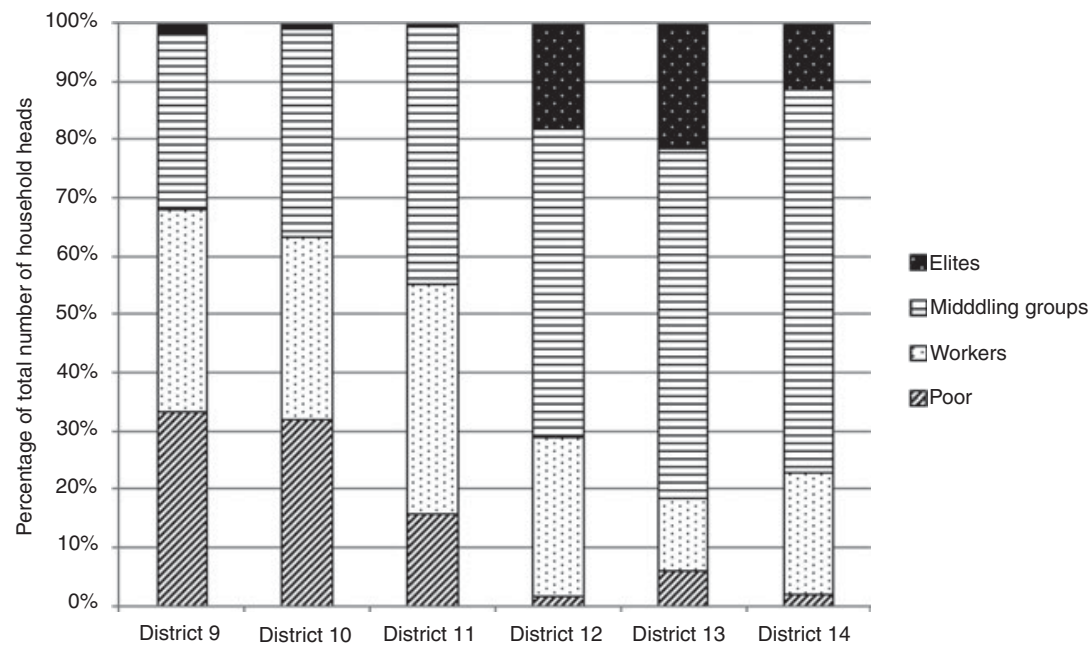

FIGURE 4. Social stratification in six Delft districts, 1749. The stratification used is based on the assessed amount of taxes, occupation, the presence of domestic servants in the household and whether people depended on poor relief. The elites included regents (charity administrators), patricians, wealthy merchants and some rentiers. The middle classes formed a large group of people working as officials, shopkeepers, craftsmen, merchants and entrepreneurs. The workers were, for example, day labourers, servants and soldiers. The households depending on poor relief were classified as poor. In most cases, they were not assessed for tax by the city, although every household had to pay at least a small sum towards national taxation. The classification used here derives from Marco H. D. van Leeuwen, De rijke Republiek: gilden, assuradeurs en armenzorg 1500-1800 (The Hague and Amsterdam, 2000), 40-3; and E. van Nederveen Meerkerk, 'Geven na de dood. Liefdadige giften en stedelijke geefcultuur in Utrecht en Zwolle, 1600-1800', Stadsgeschiedenis 2 (2010), 129-47, here 138-40. (Source: Archives Delft, Old City Archives I, inv. no. 602.)

nevertheless, 187,333 guilders in cash and 60,232 guilders in precious metals were collected, showing that morale was high in the Dutch Republic in relation to taxation. ${ }^{61}$

The notion of citizenship is also relevant for understanding the charitable-giving behaviour of the early modern Dutch. When they donated to collections, they expected their neighbours to do the same. Due to the semi-obligatory character of the collections, they could rely on that. Moreover, they trusted that the public and religious authorities would spend their money wisely. The income and expenses were registered accurately and, once or twice a year, the bursar of the charitable institutions had to permit an inspection of the account books. The authorities were aware that the public could be influenced by the financial situation of the charities. When in Delft in 1574, a surplus of some 400 guilders 
existed, it was spent on wool, sheets and shoes for the poor, because a surplus could potentially discourage churchgoers to give. ${ }^{62}$ Sometimes attempts were made to influence the policy of the charitable institutions. In 1631, the military governor Johan Wolfert van Brederode refused to donate anything to the collections in the Reformed Church in 's-Hertogenbosch, unless the diaconate provided better assistance to families of soldiers who had fallen into poverty ${ }^{63}$ In 1750 , in the same city, a group of churchgoers protested against the dismissal of minister Abdias Velingius, who was brought into disrepute because of his clandestine marriage, by threatening that in the future they would not give more than just a duit, the smallest coin possible, to the church collections. ${ }^{64}$

In the previous section, we have seen that the city authorities and the administrators of poor relief institutions tried to influence urban populations' giving behaviour by means of thorough planning and by exerting social pressure. This led to stable collection revenues overall; the treasurers could estimate quite precisely the yield of the offertories. The force of habit then must have been an important factor behind the charitable gift. For door-to-door collections taking place on a regular basis, this was certainly the case. People most probably kept a few coins close at hand for collections held periodically since they knew when they could expect an almoner or deacon on their doorstep. In Utrecht from March 1750 until February 1751, some 75 guilders were raised for the Almoners' Chamber every week. ${ }^{65}$ In Zwolle in 1735, between 2,200 and 2,500 duiten, some 800 stuivers and more or less 23 guilders were collected for the City Poor Chamber every 4 weeks (see Table 2).

Over the long term, however, the overall stability of the collection revenues is remarkable. First of all, it seems that charitable giving was not heavily influenced by economic and demographic developments. In eighteenth-century Delft, at a time when economic development stagnated, the urban population declined from about 24,000 in 1680 to 13,910 in $1749 .{ }^{66}$ Yet collection revenues - even if corrected for inflation (see Figure 5) - only slightly decreased. Thus, per capita giving increased in this period. Zwolle shows an opposite development. In 1670, the city had 10,932 inhabitants, which increased to 11,931 in 1748, while collection revenues somewhat diminished. ${ }^{67}$ Second, when we look more closely at the collection revenues, it becomes clear that a multitude of factors affected the giving behaviour of the early modern Dutch, such as armed conflicts, the frequency of collecting, the degree of anonymity, the popularity of the officiating minister and the extent to which the donors felt connected with the cause for which funds were raised. Yet, apparently, the authorities knew what tactics to use to maintain stable annual collection revenues. 


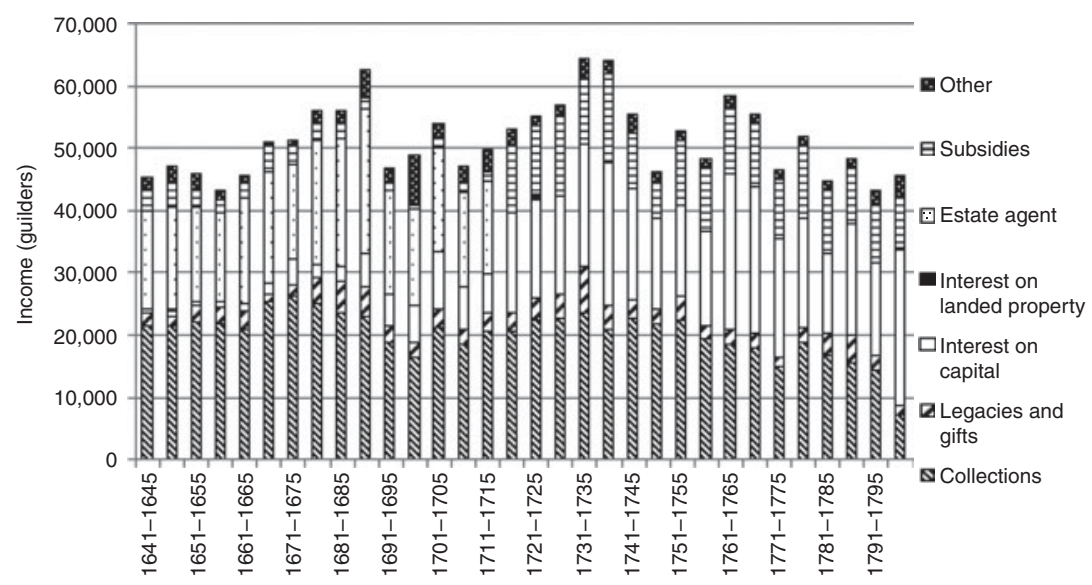

Figure 5. Amount and sources of income received by the Delft Chamber of Charity (corrected for inflation), 5-year averages, 1641-1800. The inflation correction is based on the consumer price index for the early modern period for the western part of the Netherlands as calculated by Jan Luiten van Zanden; see http://www.iisg.nl/hpw/brenv.php (last viewed 14 December 2011). On the revenues of the estate agent, see Figure 1. (Sources: Archives Delft, Chamber of Charity, inv. nos 287-290.)

In times of war, however, collection revenues could be severely disturbed. In the 'disaster year' of 1672, when the Dutch Republic was attacked on almost every front, the City Poor Chamber in Zwolle collected 25 per cent less than in the year before. ${ }^{68}$ Similarly in Utrecht, the door-to-door collections of the Almoners' Chamber yielded in 1673 only half the money collected in $1671 .^{69}$ In these cities, people were impoverished, some fled from the violence, while others were hesitant to donate generously due to the unstable political situation. To contrast, in Delft, located safely behind the Dutch Water Line, the general feeling of distress led to higher levels of generosity. In 1673, 25 per cent more money was raised than in the year before.$^{70}$ The French occupation in 1795 had a devastating effect on collection revenues in all cities. Collection revenues collapsed almost everywhere, in Delft to almost 50 per cent of their original level (see Figures 1 and 5). ${ }^{71}$

The collections that gained the highest revenues were those organised infrequently, or just once a year, such as the Christmas collection for the Chamber of Charity. The more frequently a collection took place, the smaller the sums of money people donated. For example, the Blocks in 's-Hertogenbosch raised higher amounts of money around Easter and Christmas than they did through weekly Sunday collections, although on an annual basis the weekly collection yielded more than the collections 
TABLE 3

Average collection revenues in the Reformed Church in 's-Hertogenbosch by type of service (for the period mid-September 1747 to mid-September 1750)

\begin{tabular}{lc}
\hline \hline Type of service & Collected sum (guilders) \\
\hline Regular service & 8.49 \\
Christian holiday & 13.08 \\
Days of Prayer & 40.16 \\
Lord's Supper & 100.23 \\
\hline \hline
\end{tabular}

Source: City Archives 's-Hertogenbosch, Reformed diaconate, inv. no. 454.

held twice a year. ${ }^{72}$ Collections for the assistance of fellow inhabitants within the Northern Netherlands or co-religionists in other parts of Europe usually yielded large sums. Sometimes they were preceded by a day of prayer, but there was always ample notice of such collections beforehand. Again, certain tactics were sometimes deployed to stimulate higher levels of generosity, such as collecting with open plates and letting notable persons go door-to-door to ask for charitable donations. In Delft in April 1683, both tactics were used at the same time for a collection for Protestant refugees who had fled to the Dutch Republic. The members of the city council raised more than 4,400 guilders, which was over 25 per cent of the total collected in the two Reformed churches over the entire year. ${ }^{73}$

Offertory plates were also used in churches. The Reformed Church of 's-Hertogenbosch put them on the table at every Lord's Supper ceremony; from 1747 to 1750, revenues increased almost 12-fold compared with those received via regular services (see Table 3). In Utrecht from July 1727 to July 1728, the open plates of the Lord's Supper ceremony yielded about four and a half times as much as the collection bags used during the same service, while only the members of the church could participate in the Lord's Supper. ${ }^{74}$ However, poor relief administrators were aware of the fact that these strategies to maximise collection revenues had to be used in moderation. The nine Blocks in 's-Hertogenbosch collected twice a year with open plates, while using closed boxes for the weekly collections.

Although the revenues of church collections were often quite stable on a yearly basis, the week-to-week proceeds could show major fluctuations. The number of churchgoers - which is unfortunately untraceable - and the type of service influenced how much was collected, as well as the popularity of the officiating minister. In 1590, the city council of Delft 


\section{TABLE 4}

Average collection revenues per service in the Reformed Church in 's-Hertogenbosch by officiating minister (1747-1750)

\begin{tabular}{lccc}
\hline \hline & \multicolumn{3}{c}{ Revenue (guilders) } \\
\cline { 2 - 4 } Name of minister & $\begin{array}{c}\text { Sept. 1747- } \\
\text { Sept. } 1748^{\text {a, b }}\end{array}$ & $\begin{array}{c}\text { Sept. 1748- } \\
\text { Sept. 1749 }\end{array}$ & $\begin{array}{c}\text { Sept. 1749- } \\
\text { Sept. 1750 }\end{array}$ \\
\hline Van Alphen & - & 12.67 & 10.64 \\
Clemens & 9.97 & 9.88 & 10.89 \\
Mobach & 8.13 & 9.49 & 6.31 \\
Noordberg & 3.44 & 3.20 & 3.23 \\
Velingius & 17.71 & 17.05 & 12.51 \\
De Witt & 8.74 & 7.64 & - \\
Guest ministers & 9.16 & 5.89 & 7.56 \\
\hline \hline
\end{tabular}

${ }^{a}$ The years run from mid-September to mid-September.

${ }^{b}$ The first sample year starts on 12 September 1747, during the week Abdias Velingius held his first service in 's-Hertogenbosch (on 17 September 1747). Velingius held his farewell sermon on 18 October 1750 and on that date the collection raised more than 84 guilders.

Source: City Archives 's-Hertogenbosch, Reformed diaconate, inv. no. 454.

responded to a subsidiary request of the deacons that more money could be raised if the two most eloquent ministers performed the two main services in the morning. The consistory objected that it would create inequality between the ministers and that the positive effect would be limited because the two other services would probably attract a smaller crowd. In 's-Hertogenbosch from 1747 to 1750, far more money was raised during the services of the popular minister Abdias Velingius than the other services (see Table 4). For the consistory, this profitable popularity did not justify letting him perform the main services during the week.

Feeling connected to the poor for whom charity was raised also influenced people's generosity. For all charitable giving, the cause had to be seen as worthy of support by the potential benefactors. Poor relief policy involved a clear distinction between the 'deserving poor', who were unable to work due to age or illness, and the 'undeserving poor', who were considered responsible for their own misery. The deacons and almoners closely monitored the people who they assisted so that those who they deemed had squandered their money, or were drunk or lazy, could be excluded from help..$^{75}$ As a result, when money was donated to collections for urban or religious poor relief institutions, people trusted that it would be given to those who were seen as really needing and deserving it. 


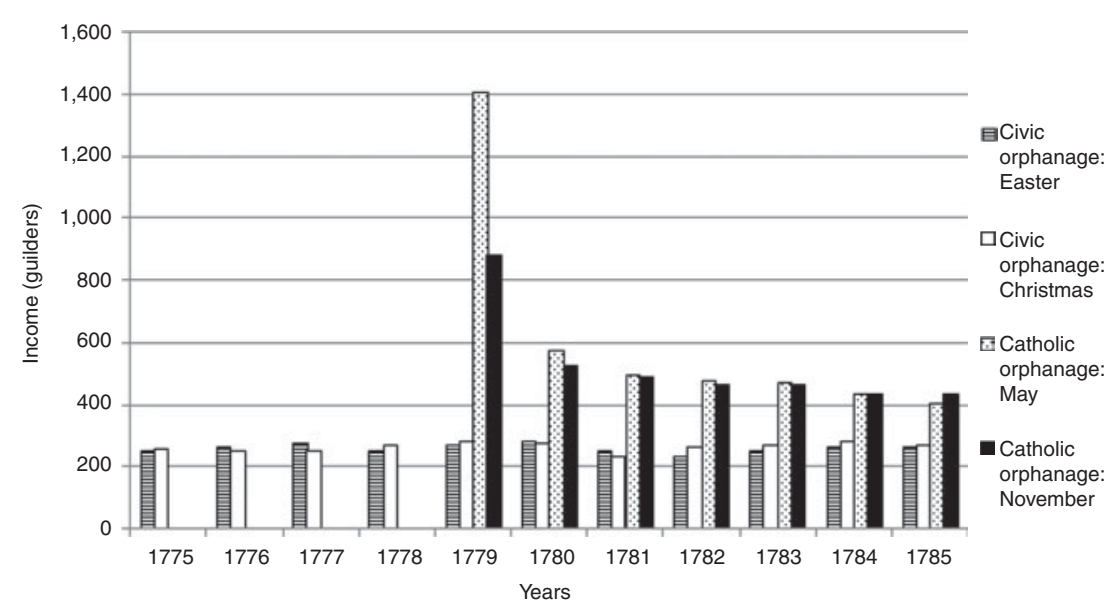

FigURE 6. Collection revenues of two orphanages in 's-Hertogenbosch, 1775-1800. For explanation of legend categories, see text. (Sources: City Archives 's-Hertogenbosch (CAH), Old Archives, inv. nos 8380-8390; CAH, Roman Catholic Orphanage, inv. nos 187-190.)

To what extent this distinction mattered can be illustrated by an example from 's-Hertogenbosch, where the collections for those detained in the city's gatehouse, which were held twice a week, yielded a paltry 5 guilders per month on average. Apparently, the majority of the urban population declined to give. ${ }^{76}$

The majority of the population in 's-Hertogenbosch stayed loyal to the Catholic Church. In 1799, 78 per cent of the population were registered as being Catholics. ${ }^{77}$ This religious affiliation was reflected in the charitable behaviour of the inhabitants of this Brabant town. The civic orphanage held public collections twice a year, around Easter and Christmas, while the newly established Catholic orphanage began to collect in the city in May and November from 1779 onwards. Although collectors for the latter only visited the homes of Catholic families, the collections for this orphanage in the early 1780s gained nearly twice as much as the collections for the civic institution (see Figure 6). When in 1794, collectors for the Catholic orphanage were allowed to increase their rounds and visit households throughout the city, the revenues did not substantially increase. The Protestant inhabitants of 's-Hertogenbosch were unwilling to contribute to a poor relief institution to which they felt no connection. ${ }^{78}$

Although churchgoers most probably donated more - or at least more often - to charitable causes than people who did not attend church, no substantial differences in charitable giving between the various religious denominations can be observed. In the second half of the eighteenth 
century in Catholic-dominated 's-Hertogenbosch, per capita giving was only slightly lower than in Zwolle, where a far smaller part of society stayed loyal to the old religion. Members of all religious communities organised collections, and Reformed as well as Catholic poor relief administrators often depended heavily on the largesse of their coreligionists. In 's-Hertogenbosch, considerable sums of money were donated; however, the collections only made up a small share of the incomes of poor relief institutions in this city because of the extremely large budgets of these charities.

\section{CONCLUSION}

In financing the relatively generous early modern Dutch poor relief system, collections were of vital importance. Money that was collected in the churches and in the streets was often the single largest source of income for charitable institutions taking care of the outdoor poor, especially in the seventeenth century. Extra collections could furthermore solve acute financial problems and display compassion and solidarity towards fellow inhabitants of the Northern Netherlands or co-religionists in other parts of Europe.

This article argues that donating to these collections had a semiobligatory character; contributions were expected from all city-dwellers who could miss a few coins. A large majority of the urban population were accustomed to making monetary charitable donations on a regular basis. This confirms that as early as the seventeenth century, the Dutch Republic was a highly monetised society. Even for the lower-class Dutch, it was probably common to put a duit in the offertory bags. However, as everyone was expected to donate according to their means, the small coins donated by the lower social groups did not contribute substantially to the income of charitable institutions. Apart from the small but wealthy upper class, the large middling groups of society were of vital importance for the financing of early modern Dutch poor relief.

Analysis of long-term collection yields shows a remarkable stability, suggesting that donations made through regular door-to-door collections were subject to the force of habit. Nevertheless, a multitude of factors influenced the revenues from collections, such as armed conflicts, the frequency of collecting, the popularity of the officiating minister and the extent to which the donor felt connected with the cause for which funds were raised. However, the authorities tried to influence the giving behaviour of the population through the use of thorough planning and the application of social pressure, and overall managed to maintain annual collection revenues at a stable level. 
Why did the inhabitants of the Dutch Republic finance such a large part of poor relief through charitable gifts? The region of the Northern Netherlands was the most urbanised in Europe. In the cities, where rich and poor lived in close proximity, a well-functioning poor relief system was not just a virtue but, in fact, a necessity. Fear of social unrest and the social pressure applied by the authorities, as well as civic commitment and pride, encouraged the early modern Dutch to contribute to charitable collections. As a result of the supervision and regulation by the city governments, city-dwellers could expect that everyone would contribute and that the money would be wisely spent.

\section{ACK NOWLEDGEMENTS}

This article was written as part of the research project 'Giving in the Golden Age', financed by the Netherlands Organisation for Scientific Research (NWO), and is based on ongoing doctoral research. I would like to thank the editors and referees of Continuity and Change, as well as my colleagues at the Research Department of the International Institute of Social History for their comments on earlier versions of this article, in particular Lex Heerma van Voss, Marco van Leeuwen, Henk Looijesteijn, Jan Lucassen and Elise van Nederveen Meerkerk. The text was edited by Nazima Kadir.

\section{ENDNOTES}

1 See, for example, Marco H. D. van Leeuwen, 'Logic of charity: poor relief in preindustrial Europe', Journal of Interdisciplinary History 24 (1994), 589-613; Abraham de Swaan, In care of the state: health care, education, and welfare in Europe and the USA in the modern era (New York, 1988).

2 Van Leeuwen, 'Logic of charity', 608.

3 Jan de Vries and Ad van der Woude, The first modern economy: success, failure and perseverance of the Dutch economy, 1500-1815 (Cambridge, 1997), 60-1.

4 Marco van Leeuwen distinguishes five social groups: the elites (less than 10 per cent of the population), the upper middle class (over 10 per cent of the population), the lower middle class (over a third of the population), lower social groups (a little less than a third of the population) and the lowest social group (over 10 per cent of the population), see Marco H. D. van Leeuwen, De rijke Republiek: gilden, assuradeurs en armenzorg 1500-1800 (The Hague and Amsterdam, 2000), 40-3.

5 On the Dutch 'bourgeois' society, see, for example, Maarten Prak, 'The Dutch Republic as a bourgeois society', BMGN 125, 2-3 (2010), 107-39; J.L.Price, Dutch society 1588-1713 (London, 2000), especially ch. 4, 'A bourgeois society?'.

6 Leo Noordegraaf and Jan Luiten van Zanden, 'Early modern economic growth and the standard of living: did labour benefit from Holland's Golden Age?', in Karel Davids and Jan Lucassen eds., A miracle mirrored. The Dutch Republic in European perspective (Cambridge, 1995), 410-37.

7 Lee Soltow and Jan Luiten van Zanden, Income and wealth inequality in the Netherlands 16th-20th century (Amsterdam, 1998), ch. 3. See, also, Bas van Bavel, 'The medieval origins of capitalism in the Netherlands', BMGN 125, 2-3 (2010), 45-79. 
8 Manon van der Heijden, 'De spanning tussen gemeenschap en individu: sociaalculturele ontwikkelingen', in Karel Davids and Marjolein 't Hart eds., De wereld en Nederland: een sociale en economische geschiedenis van de laatste duizend jaar (Amsterdam, 2011), 143-4.

9 Tine de Moor and Jan Luiten van Zanden, Vrouwen en de geboorte van het kapitalisme in West-Europa (Amsterdam, 2006), 77.

10 Maarten Prak, 'Armenzorg 1500-1800', in Jacques van Gerwen and Marco H. D. van Leeuwen eds., Studies over zekerheidsarrangementen: risico's, risicobestrijding en verzekeringen in Nederland vanaf de Middeleeuwen (Amsterdam, 1998), 49-90, here 71-5.

11 Peter H. Lindert, 'Poor relief before the welfare state: Britain versus the continent, 1780-1880', European Review of Economic History 2 (1998), 101-40.

12 McCants states that the middle classes in particular contributed to excise taxes: Anne E. C. McCants, Civic charity in a Golden Age. Orphan care in early modern Amsterdam (Urbana and Chicago, 1997), 9.

13 However, several studies were conducted on the financing of poor relief within individual cities; see, for example, José de Kruif, 'De prijs van de armenzorg. De financiering van de armenzorg in Den Bosch 1750-1900', Tijdschrift voor Sociale Geschiedenis 20 (1994), 24-51; Marco H. D. van Leeuwen, 'Amsterdam en de armenzorg tijdens de Republiek', NEHA-Jaarboek 95 (1996), 132-61 (for an English version, see Marco H. D. van Leeuwen, 'Overrun by hungry hordes? Migrants' entitlements to poor relief in the Netherlands, 16th-20th centuries', in S. Hindle and A. Winter eds., Migration, settlement and belonging in Europe, 1500-2000: comparative perspective (forthcoming)).

14 For a map of the Dutch Republic and the location of the cities discussed here, see Figure 1 in Elise van Nederveen Meerkerk, 'The will to give: charitable bequests and community building in the Dutch Republic, c.1600-1800', in this issue of Continuity and Change. Delft is situated in the province of Holland, to the southwest of Leiden.

15 On religious as well as secular motivations behind charity, see Henk Looijesteijn, 'Funding and founding private charities: Leiden almshouses and their founders, 1450-1800'; Van Nederveen Meerkerk, 'The will to give'; and Marco H. D. van Leeuwen, 'Giving in early modern history: philanthropy in Amsterdam in the Golden Age', all in this issue of Continuity and Change.

16 The system of letters of surety ('actes van indemniteit'), guaranteeing that the municipality or a poor relief institution in a migrant's former residence would pay for assistance if he were to fall into poverty within a specified number of years had, however, been initiated by provincial legislation.

17 Elise van Nederveen Meerkerk and Griet Vermeesch, 'Reforming outdoor relief. Changes in urban provisions for the poor in the Northern and Southern Low Countries (c. 1500-1800)', in Manon van der Heijden, Elise van Nederveen Meerkerk, Griet Vermeesch and Martijn van der Burg eds., Serving the urban community. The rise of public facilities in the Low Countries (Amsterdam, 2009), 135-54, here 138-43. An exception is the province of Frisia, where in some towns, charity funds were centralised in the first half of the sixteenth century: Joke Spaans, 'De gift aan de armen in Friese steden in de zestiende, zeventiende en achttiende eeuw: toegelicht aan het voorbeeld van Sneek', Tijdschrift voor Sociale Geschiedenis 22 (1996), 375-93, here $375-7$.

18 On the poor relief provisions in different localities in the Dutch Republic, see Van Nederveen Meerkerk and Vermeesch, 'Reforming outdoor relief', 143-8; Charles 
H. Parker, The reformation of community. Social welfare and Calvinist charity in Holland, 1572-1620 (Cambridge, 1998), 157-87. On the city of Utrecht, see Daniëlle Teeuwen, " "Vande groote swaricheyt der armen deser Stadt". De reorganisatie van de armenzorg in Utrecht, 1580-1674', Jaarboek Oud-Utrecht (2010), 48-65.

19 On the income structure of the House of Giving and the Blocks, see De Kruif, 'De prijs van de armenzorg'.

20 Marco H. D. van Leeuwen, 'Histories of risk and welfare in Europe during the 18th and 19th centuries', in O. P. Grell, A. Cunningham and R. Jütte eds., Health care and poor relief in 18th and 19th century Northern Europe (Aldershot, 2002), 32-66.

21 On Utrecht, see Teeuwen, " "Vande groote swaricheyt der armen deser Stadt", , 61-2; on Delft, see Ingrid van der Vlis, Leven in armoede. Delftse bedeelden in de zeventiende eeuw (Amsterdam, 2001), 60-1.

22 Historical Centre Overijssel (hereafter HCO), City Archives, inv. no. 85, 13 November 1739; HCO, City Archives, inv. no. 88, 6 February 1756. On the Catholics, also see Hilde van Wijngaarden, Zorg voor de kost. Armenzorg, arbeid en onderlinge hulp in Zwolle, 1650-1700 (Amsterdam, 2000), 78-9.

23 Van Nederveen Meerkerk and Vermeesch, 'Reforming outdoor relief', 142.

24 In Delft, Zwolle and Utrecht, for example, fees paid to the city council to allow a couple to be married outside the city were given to the public charities; see, for example, Archives Delft (hereafter AD), Chamber of Charity, inv. no. 289; HCO, City Archives, inv. no. 10125; Utrecht Archives (hereafter UA), Almoners' Chamber, inv. no. 1827 part 32 .

25 This poor tax also existed in Schiedam. It was possible to pay this duty off in cash: Van der Vlis, Leven in armoede, 326-40; Ingrid van der Vlis, " "Hebben wij niet schade genoech geleeden?" Zeventiende-eeuwse Delftenaren over armenzorgbelasting', Tijdschrift voor Sociale Geschiedenis 22 (1996), 394-416.

26 UA, Almoners' Chamber, inv. no. 1825 part 8, 17 October 1628.

27 De Kruif, 'De prijs van de armenzorg'. Orphanages, hospitals and other organisations caring for the 'indoor poor' often had substantial endowments as well. It would have been too hazardous to rely too much on charitable donations, for these institutions could not so easily cut back on their expenses: McCants, Civic charity in a Golden Age, 152.

28 In Utrecht, there are no financial data available for the Reformed diaconate for the seventeenth century, but in the eighteenth century, more than half of the income came from the proceeds of collections and this proportion is unlikely to have been lower in the century before.

29 AD, Chamber of Charity, inv. nos 287-290. The money put into alms boxes as a share of the total amount collected per year in the city has been calculated for the sample periods 1641-1650, 1671-1680, 1701-1710, 1731-1740, 1761-1770 and 1791-1800.

30 HCO, City Poor Chamber, inv. no. 91; HCO, City Archives, inv. nos 10105-10106 and 10124-10125. The money put into alms boxes as a share of the total amount collected per year in the city has been calculated for the sample periods $1661-1670,1751-1760$, 1771-1780 and 1791-1800.

31 AD, Old City Archives I, inv. no. 17.8, 29 January 1778. The municipality donated 125 guilders to Giesendam.

32 AD, Old City Archives II, inv. no. 1.8, 26 November 1800.

33 HCO, Roman Catholic Poor Chamber, inv. no. 6, 29 November 1739. 
34 See for this, and other determinants of giving, Lex Heerma van Voss and Marco H. D. van Leeuwen, 'Charity in the Dutch Republic: an introduction', in this issue of Continuity and Change.

35 In Delft, for example, two or three services were held on Sundays and one or two during weekdays in the Reformed church. See AD, Chamber of Charity, inv. nos 373-384.

36 This was, for example, the case for the Mennonites in Amsterdam: S. Groenveld, " "Geef van uw haaf een milde gaaf ons arme weesen": de zorg voor wezen, tot 1800, als onderdeel van de armenzorg', in S. Groenveld ed., 'Daar de Orangie-appel in de gevel staat': in en om het weeshuis der doopsgezinde collegianten, 1675-1975 (Amsterdam, 1975), 9-52, here 37. The Mennonites in Zwolle presumably also did not collect during service, see: HCO, Mennonite Church, inv. no. 155.

37 For the frequency of collections, see the financial records of the charitable institutions: UA, Almoners' Chamber, inv. no. 1827; AD, Chamber of Charity, inv. nos 287-290; City Archives 's-Hertogenbosch (hereafter CAH), Blocks, annual account books Blocks A to I; HCO, City Poor Chamber, inv. no. 91; HCO, City Archives, inv. nos 10105-10111 and 10124-10125; HCO, Roman Catholic Poor Chamber, inv. no. 43; HCO, Reformed Church, inv. no. 323.

38 CAH, Old Archives 's-Hertogenbosch, inv. nos 8289-8413; CAH, Roman Catholic Orphanage, inv. nos 187-205.

39 CAH, Poor prisoners, inv. nos 30-59.

40 In 's-Hertogenbosch, permission to organise extra collections was granted several times because of extreme winters, see, for example: CAH, Reformed diaconate, inv. no. 7, 21 January 1767.

41 The number of poor boxes are sometimes mentioned in the account books of the charitable institutions: CAH, Blocks, annual accounts Blocks A to I; CAH, Reformed diaconate, 257-94. For the alms boxes in Amsterdam, see Van Leeuwen, 'Giving in early modern history'.

42 On charitable bequests in the Dutch Republic, see Van Nederveen Meerkerk, 'The will to give'.

43 Van Leeuwen, 'Amsterdam en de armenzorg', 141. Also, see Spaans, 'De gift aan de armen', 383.

44 A 'day of prayer' is a Dutch Protestant day of contemplation, announced by provincial or national authorities, on which gratitude to the Lord is expressed and prayers are said to victims of wars, famine and disasters.

45 AD, Old City Archives I, inv. no. 1.10, 8 June 1749.

46 See, for example, CAH, Reformed diaconate, inv. no. 1, 7 January 1689.

47 Donating to collections was sometimes called a 'plicht' meaning 'duty', see, for example: AD, Old City Archives II, inv. no. 29.1, 13 November 1796.

48 For an example where the wealthy were especially urged to give, see: UA, City Archives I, inv. no. 121, 8 February 1740 . For a charitable appeal in which every inhabitant of Zwolle was asked to donate, see, for example: HCO, City Archives, inv. no. 805, 6 February 1699.

49 See, for example, AD, Old City Archives I, inv. no. 1.6, 19 December 1621. Joke Spaans notes that in Haarlem, if the collectors found no one home, they tried again at a later time: Spaans, 'De gift aan de armen', 382.

50 Quoted in McCants, Civic charity in a Golden Age, 10.

51 Spaans, 'De gift aan de armen', 386-91.

52 On the debate, see Ilana Krausman Ben-Amos, The culture of giving. Informal support and gift-exchange in early modern England (Cambridge, 2008), 83-4.

53 See Van Nederveen Meerkerk, 'The will to give'. 
54 HCO, City Archives, inv. nos 11276-11279. The explanation that someone was too poor to donate was given for six per cent of the households, which was also the share of the urban population at the time that depended on poor relief: Van Wijngaarden, Zorg voor de kost, 86. According to the account books of the Holdehuis, some 11,000 guilders were collected; see HCO, City Archives, inv. no. 11280. However, the donations in the registers add up to a little less than 9,000 guilders.

55 Van Wijngaarden, Zorg voor de kost, 38-41.

56 N. D. B. Habermehl, 'De bevolkingssamenstelling in Zwolle van 1628 tot 1748', Zwols Historisch Jaarboek (1984), 73.

57 See, for example, AD, Old City Archives I, inv. no. 1.3, 25 November 1576.

58 On the residential segregation in Delft in the early nineteenth century, see Clé Lesger and Marco H. D. van Leeuwen, 'Residential segregation from the sixteenth to the nineteenth century: evidence from the Netherlands', Journal of Interdisciplinary History 42, 3 (2011), 333-69, here 350-5.

59 Marco H. D. van Leeuwen, 'Guilds and middle-class welfare, 1550-1800: provisions for burial, sickness, old age, and widowhood', Economic History Review 65, 1 (2012), 61-90, here 85-6.

60 Jan Luiten van Zanden and Maarten Prak, 'Towards an economic interpretation of citizenship: The Dutch Republic between medieval communes and modern nationstates', European Review of Economic History 10 (2006), 111-45; Maarten Prak and Jan Luiten van Zanden, 'Tax morale and citizenship in the Dutch Republic', in Oscar Gelderblom ed., The political economy of the Dutch Republic (Ashgate, 2009), 143-65, here 144.

61 Prak and Van Zanden, 'Tax morale and citizenship', 154.

62 P. H. A. M. Abels, Nieuw en ongezien. Kerk en samenleving in de classis Delft en Delfland 1572-1621. II: De nieuwe samenleving (Delft, 1994), 217.

63 Aart Vos, Burgers, broeders en bazen. Het maatschappelijk middenveld van 'sHertogenbosch in de zeventiende en achttiende eeuw (Hilversum, 2007), 321.

$64 \mathrm{CAH}$, Reformed diaconate, inv. no. 5, 17 September 1750. The church members' protest was, however, unsuccessful.

65 UA, Almoners' Chamber, inv. no. 1827 part 41.

66 Th. F. Wijsenbeek-Olthuis, Achter de gevels van Delft (Hilversum, 1987), 27.

67 On the number of inhabitants in Zwolle, see Jan Lucassen and Piet Lourens, Inwonersaantallen van Nederlandse steden ca. 1300-1800 (Amsterdam, 1997), 83-4. On the collection revenues in the years 1670 and 1748, see HCO, City Archives, inv. nos 10106 and 10125 .

68 HCO, City Archives, inv. nos 10106-10107.

69 UA, Almoners' Chamber, inv. nos 1827 part 7.

70 AD, Chamber of Charity, inv. no. 287.

71 AD, Chamber of Charity, inv. no. 290.

72 CAH, Blocks, annual account books block A to I.

73 AD, Old City Archives I, inv. no. 1231; AD, Chamber of Charity, inv. no. 288.

74 UA, Reformed diaconate, inv. no. 538.

75 See, for example, A. Buursma, 'Dese bekommerlijke tijden': armenzorg, armen en armoede in de stad Groningen 1594-1795 (Assen, 2009), 112-17.

$76 \mathrm{CAH}$, Poor prisoners, inv. no. 59; CAH, Old Archives 's-Hertogenbosch, inv. no. 3110.

77 Vos, Burgers, broeders en bazen, 268-9.

78 CAH, Roman Catholic Orphanage, inv. nos 197-200. 
Collectes pour les pauvres: donations charitables dans les villes hollandaises, c. $1600-1800$

Dans de nombreuses localités de la République hollandaise, les quêtes à but caritatif étaient la plus grande source de revenu pour les institutions charitables en charge de pauvres vivant à domicile, à l'extérieur de ces institutions. Cet article prend en compte à la fois le rôle des autorités organisant des quêtes et le rôle des habitants de la ville faisant des donations charitables. Il ressort que presque toutes les couches de la société urbaine contribuaient aux collectes. Grâce à une planification minutieuse et à la pression sociale exercée, les administrateurs religieux et laïcs de l'aide aux pauvres essayaient de toujours faire croître la générosité hollandaise. Faire don aux institutions caritatives était présenté comme un devoir des riches aussi bien qu'un devoir des moins aisés. Dans la République hollandaise, c'était non seulement des élites, mais aussi des classes moyennes (ces dernières formant approximativement la moitié de la population urbaine), que dépendait le financement vital de l'aide aux pauvres.

Sammlungen für die Armen: Geldspenden für wohltätige Zwecke in niederländischen Städten, ca. 1600-1800

In vielen Orten der Niederländischen Republik bildeten wohltätige Sammlungen die größte Einkommensquelle der Fürsorgeeinrichtungen für die nicht in Armenhäusern untergebrachten Armen. Dieser Beitrag beschäftigt sich sowohl mit der Rolle der städtischen Obrigkeit bei der Organisation von Geldsammlungen als auch mit der Rolle der Stadtbewohner, die Geld für wohltätige Zwecke spendeten. Es zeigt sich, dass Leute aus beinahe allen Schichten der städtischen Gesellschaft zu den Geldsammlungen beitrugen. Die geistlichen und weltlichen Verwalter der Armenfürsorge versuchten, durch gründliche Planung, aber auch, indem sie sozialen Druck erzeugten, die niederländische Großzügigkeit zu maximieren, und stellten es als eine Pflicht der Reichen, aber auch der weniger Wohlhabenden dar, für wohltätige Zwecke zu spenden. In der Republik der Niederlande waren nicht nur die gesellschaftlichen Eliten, sondern auch die Mittelschichten, die annähernd die Hälfte der städtischen Bevölkerung ausmachten, für die Finanzierung der Armenfürsorge unerlässlich. 